\title{
ASEAN Economic Cooperation: Trade Liberalization Impacts on the National Economy
}

\author{
Sugiharso Safuan \\ Correspondence: Sugiharso Safuan, Department of Economics, University of Indonesia, Depok 16424, Indonesia, \\ Tel : 62-21-7888-6252. E-mail: sugiharso@ui.ac.id
}

Received: August 4, 2012

Accepted: September 24, 2012

Online Published: September 28, 2012

doi:10.5539/ijef.v4n11p66

URL: http://dx.doi.org/10.5539/ijef.v4n11p66

\begin{abstract}
This study aims to analyse the impact of trade liberalization by focusing on twelve priority industrial sectors in the ASEAN-5 (Singapore, Thailand, Indonesia, Malaysia and the Philippines). The General Equilibrium Model based on Multi-country Input Output Data as provided by the GTAP is used to measure potential economic benefits of reducing tariffs on output, trade balance, welfare gain, and competitiveness. We compare the outcome of the CGE approach with the Cost Benefit Analysis (CBA) based on the Analytical Hierarchy Process (AHP). The results show that the outcomes of the CGE Model does not match those suggested by the AHP. However, they do support the findings of Falianty (2005), Achsani and Siregar (2010), Achsani and Partisiwi (2010), Nugroho and Yanfitri (2011). Our results suggest that taking non-economic but relevant factors from public opinion into account affects the robustness of CGE studies based purely on economic factors.
\end{abstract}

Keywords: ASEAN-5, economic integration, tariff liberalization, welfare

\section{Introduction}

After the year 2000, rapid movement towards the conclusion of the Free Trade Area (FTA) in East Asia has been a subject of intensive investigation among researchers. In particular, there is a need to understand the distribution of the potential economic benefits resulting from trade liberalization under economic integration (see: Urata and Kiyota, 2003; Francois and Wignaraja,2008; Pardo-Calvo, Freund, C.L and, Omelas, L,2009; Mukopadhyay and Thomassin, 2010). In a similar spirit, see Falianty (2006); Achsani and Siregar (2010); Achsani and Partisiwi (2010); and Nugroho and Yanfitri (2011).

Francois and Wignaraja (2008) examined three core scenarios - ASEAN+3, ASEAN+3 and India, and ASEAN +3 and South Asia. The analysis concluded that China, Japan, and Korea were countries that drove most of the income and trade effects in the East Asia region across all scenarios. Pardo et.al (2009) studied the effects of preferential and external tariff reductions on import growth from ASEAN and non-ASEAN. They found no evidence that preferential liberalization has led to lower import growth from non-members.

Falianty (2006) used data from the ASEAN-5 countries (Singapore, Malaysia, Thailand, Indonesia and the Philippines) to analyze the readiness of these countries to implement the idea of single currency. Her findings show that not all countries are ready to joint, particularly Indonesia and the Philippines. Using a different approach, Achsani and Siregar (2010) extended the number of countries under their study and came to a similar conclusion. In line with this, Achsani and Siregar (2010) analyzed potential economic benefits by classifying countries according to the limitation and among member countries of the ASEAN +3 . Nugroho and Yanfitri (2011) assessed the implication of the agreement of ASEAN Economic Cooperation toward establishment of a single market in the year 2015 for the Indonesian economy. The study used quantitative and qualitative data from the ASEAN +3 . The findings indicate that Indonesia still needs to enhance commitment among stakeholders in order to achieve optimal potential economic benefits from the program. The findings are also consistent with previous studies, as the data support the hypothesis of the existence of disparity of potential economic benefits among ASEAN member countries.

In January 2007, under the ASEAN Economic Cooperation framework, at the 12th ASEAN Summit, the ASEAN Country Leaders affirmed their strong commitments to accelerating the establishment of an ASEAN Community by 2015. As part of the agreement, tariffs on all intra-ASEAN goods will be eliminated in accordance with the schedules and commitments set out in the CEPT-AFTA Agreement and other relevant Agreements. Progress achieved with respect to the removal of tariffs is as follow: 
- $\quad$ All tariffs on eight sectors and sub-sector ( agro-based, fisheries, healthcare, electronic, rubber based, wood based, textiles, and automotive) were eliminated by Singapore (since 2002), Malaysia and Thailand ( since 2009)

- Indonesia and the Philippines have eliminated all tariffs on six sector and sub-sector, namely health care, electronic, rubber, textiles (since 2008), wood based, and automotive (since 2009),

- Indonesia and the Philippines are still collecting taxes 0-3\% two sub-sectors which are agro-based sub-sector ( code 7.14 and 10.5) and fisheries sub-sector (code 3.01 and 3.04). (The ASEAN Secretariat, 2010).

With respect to the distribution of the gains from trade (Deardorff, 1984), there has been no sufficient policy evaluation, particularly in identifying who is the winners as well as the losers. Clarification on this issue is very important to the country members as well as to the stakeholder of the AEC to decide what should be done to achieve maximum benefits from such agreement.

Our study ties in with a number of recent studies, including a study by Mukopadhyay and Thomassin (2010) that analyzes tariff reduction using various scenarios and regionalism (clustering) of trade agreement (i.e. ASEAN and non-ASEAN Countries). It was unclear whether tariff reduction would create equal potential beneficial effects to all members. Our approach extends Mukopadhyay and Thomassin's study by providing different clustering alternatives based on more recent data. The gist of our approach is to compare the relative impact of tariff reduction of priority integration sector (PIS) on country's welfare and competitiveness among the ASEAN-5 (Indonesia, Singapore, Thailand, the Philippines, and Malaysia).

The remainder of this paper is organized as follows. Section 2 explains data and research methodology. Results and discussion will be presented in section 3. The final section of the paper gives a conclusion and policy recommendation.

\section{Data and Methodology}

\subsection{Data Aggregation}

We used the GTAP version 7 database to analyze the impact of tariff liberalization on 12 priority sectors for integration on national economy of each country. The GTAP database is a global database that contains bilateral trade patterns, transport, production data, and consumption, intermediate use of commodities and services, protection data characterizing economic linkages among region, together with individual-country input-output data bases that account for inter-sector linkages within each region. The advantage of using a multi-country model is to take into account the impact of a changing world environment, as well as the possible feedback associated with the bilateral trade liberalization.

The GTAP database of this version comprises 113 countries, 57 sectors. Our study focuses on the ASEAN-5 and the 12 priority sectors whose tariffs will be eliminated in accordance to the schedule and commitments of the governments of the ASEAN countries. Before analyzing, the first step is to aggregate the 113 countries into seven regions: (a) Indonesia; (b) Singapore; (c) Thailand; (d) Philippines; (e) Malaysia; (f) the rest of ASEAN, and (g) the rest of the world. We then aggregate the 57 sectors into twelve priority sectors: (i) agro-based product; (ii) air transport; (iii) automotive; (iv) E-ASEAN; (v) electronic goods; (vi) fisheries; (vii) health product; (viii) rubber; (ix) textile and clothing; (x) tourism; (xi) wood; and (xii) logistic. Table 1 depicts products included in each of the aggregated sector.

\subsection{General Equilibrium}

The impact of tariff reduction on the performance of national economic is analyzed within the framework of Walrasian general equilibrium (WGE), originally developed by Walras (1874). The advantage of this approach is its ability to measure policies' ultimate impact on aggregate welfare in an economy.

According to this theories, whole economy $\left(W^{e}\right)$ can be viewed as an interconnected of single market (consumer). Suppose that $W^{e}=\left\{\left[u^{i}, x^{0^{i}}\right]\right\}_{1}^{n}$ denotes an economy where $\left[u^{1}, x^{0^{1}}\right], \ldots\left[e^{n}, x^{0^{n}}\right]$ is a pair of consumer choices. $n$ is number of consumer. Walrasian Equilibrium is a pair $\left(p^{*}, x^{*}\right) \in R_{+}^{l} \times R_{+}^{n l}$ that satisfies the following two conditions: Firstly, $\forall_{1 i} \in\{1,2,3, \ldots, n\}: x^{* i}$ maximizes $u^{i}$ on the budget constraint, $B\left(p^{*}, x^{* i}\right):=\left\{x^{i} \in R_{+}^{l} \mid p^{*} \cdot x^{i} \leq p^{*} \cdot x^{0^{i}}\right\}$. where $\left\{x^{* 1}, x^{* 2}, x^{* 3}, \ldots, x^{* n}\right\}$ is bundles of individual consumer's demand and $\left\{p^{* 1}, p^{* 2}, p^{* 3}, \ldots, p^{* n}\right\}$ is set of prices. Secondly, $\forall_{k} \in\{1,2,3, \ldots, l\}: \sum_{i=1}^{n}\left[x_{k}^{* i}-\right.$ $\left.x_{k}^{o i}\right] \leq 0$ and $\sum_{i=1}^{n}\left[x_{k}^{* i}-x_{k}^{o 1}\right] \leq 0$ if $p_{k}^{*} \geq 0$.

The second condition is for market clearing. In this definition, the price plays the role of equilibrating demand and supply. In modern economics literature, the concept of Walrasian general equilibrium has been intensively studied (see Arrow and Debreu (1959)). In Arrow and Debreu (1959), the abstract of computable general 
equilibrium structure (CGE) is formalized to solve numerically for the levels of supply and demand, and prices that support equilibrium across a specified set of markets.

In a number of empirical studies (Shield and Francois (1994), Gunning and Keyzer (1995), Wing (2004)), the CGE has been used as a standard tool to analyze the aggregate welfare as well as the impact of policies whose effects may be transmitted through multiple markets or region. The policies can be a price-based (e.g. taxes and subsidies) or quantity based (e.g. demand and /or supply constraint and whose values are exogenously determined by the researcher). Under this approach, the impact of policies can be evaluated by comparing the pre-and the post change equilibrium vector of prices, demand and income level.

\subsection{GTAP}

GTAP (Global Trade Analysis Project) is a quantitative model developed based on the General Equilibrium Theory. The model has been widely used by researchers and policy makers to conduct quantitative analysis of international policy issues. We use the GTAP model to analyze the impact of tariff liberalization on national economy. The basic setup of this multi-country model assumes that representative agents in the economy comprise household, and firm ${ }^{1}$. Each regional household or country has representative consumers that maximize their utility function, dependent on private consumption of good, savings and government expenditures. According to Hertel (1997), the aggregate utility is governed by the Cobb Douglas function. Solving this problem yields three forms of representative agent's demand functions respectively for: (1) government; (2) household; (3) and saving.

a. Household Expenditure :

$$
\begin{aligned}
& \operatorname{INCOME}(r)+u(r)=\operatorname{PRIEX}(r)+u p(r)+\operatorname{GOVEX}(r) \\
& \quad+[u g(r)-\operatorname{pop}(r)]+\operatorname{SAVE}(r)[q \operatorname{saver}(r)-\operatorname{pop}(r)]
\end{aligned}
$$

b. Regional Saving :

$$
\text { qsaver }(r)=y(r)-\operatorname{psaver}(r)-\operatorname{saveslack}(r)
$$

c. Government Purchases :

$$
U g(r)=y(r)-\operatorname{pgov}(r)+\operatorname{govslack}(r)
$$

Each industry of each country or region assumes a nested Constant Elasticity of Substitution (CES). It combines the input factors of production (land, capital, skilled labor, unskilled labor and intermediate goods. Their quantities are denoted as $Q F E=(i, j, s)$. Firms also purchase intermediate inputs, some of which are produced domestically afds $(i, j, s)$ and some of which are imported $\operatorname{qfm}(i, j, s)$. This specification is known as "Armington approach". The firms combine their individual input factors to produce output, $Q O(i, s)$, under the assumption of separability in production.

The model assumes that firms choose their optimal mix of primary factors, independent of the price of intermediate inputs. The degree of substitution between any individual primary factors and intermediate input is equal and is given by the elasticity of substitution parameter. Prices of goods and production factors are determined through interaction between demand and supply in the markets. Prices are determined in the goods market simultaneously.

\subsection{AHP}

The Analytic Hierarchy Process (AHP) was originally developed by Saaty (1987). The AHP methodology has gained popularity in many area of empirical studies since it provides not only a framework for decision $\mathrm{m}$, but making also takes into account all the relevant quantitative and qualitative relevant information in achieving the stated objective. In general, this approach allows the researcher/policy maker to analyse multi-criteria decision problems which are decomposed in a hierarchy of criteria, sub-criteria, attributes and alternatives.

The main purpose of this study is to use the result of the AHP to examine the robustness of the results based on the CGE model. As documented in Saaty (1990), the first step to implement this approach is to identify a hierarchy or network structure to represent a decision problem. Secondly, using the hierarchy to develop priorities for the alternatives based on the expert's judgments throughout the system. In ideal case of exact measurement, the quantified judgment are recorded in pairs and presented in matrix form so called a pairwise comparison matrix, A. Suppose that $\mathrm{C}_{1}, \mathrm{C}_{2}, . ., \mathrm{C}_{\mathrm{n}}$ be $n$ the element of activities. The quantified judgments on pair of activities $\mathrm{C}_{\mathrm{i}}$ and $\mathrm{C}_{\mathrm{j}}$ are represented by an $n$-by-n matrix. $\mathrm{A}=\left(\mathrm{a}_{\mathrm{ij}}\right),(i, j=1,2,3, . ., n)$. Thus the matrix $\mathrm{A}$ has the following form: 


$$
\mathrm{A}=\left[\begin{array}{cccc}
a_{11} & a_{12} & \ldots & a_{1 n} \\
a_{21} & a_{22} & \ldots & a_{2 n} \\
\ldots & \ldots & \ldots & \ldots \\
a_{n 1} & a_{n 2} & \ldots & a_{n n}
\end{array}\right]
$$

The two conditions must be hold are : (1) $a_{11}=a_{22}=\cdots=a_{n n}=1$

$$
\text { (2) if } a_{i j}=\theta \text { then } a_{j i}=1 / \theta, \theta \neq 0
$$

According to Saaty (1990), a set of numerical weights $w_{1}, w_{2}, w_{3} \ldots, w_{n}$ reflects the recorded judgment. Hence, the pairwise comparison matrix can be represented as follow :

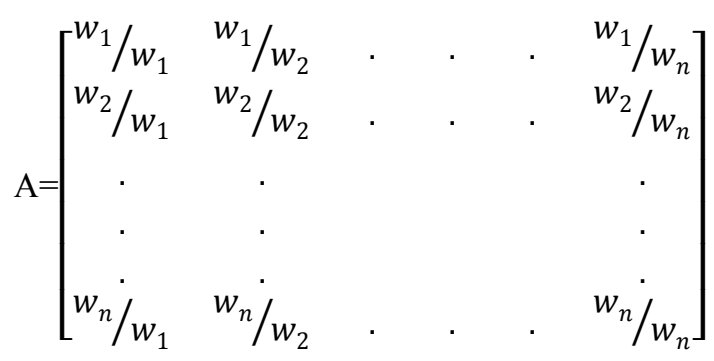

Where $w_{i} / w_{j}=a_{i j}$ for $i, j=1,2,3, \ldots n$

Once all weights in matrix A have been estimated, the next step is to synthesize the judgment by calculating the priority of each criterion in terms of its contribution to the overall goal through a normalization process of the pairwise comparison matrix. The final step is to check the consistency of entire hierarchy which is evaluated based on the consistency Index (CI) and the consistency ratio of hierarchy (CRH) developed in Saaty (1990).

There have been a number of empirical studies that have used the framework of AHP as an alternative approach to consider a non-economic variables in to the analysis, such as cost benefit analysis (CBA) (Azis, 1990, Clayton et al.1993; Wedley et al., 2001; Handfield et al., 2002). In this study, we adopt their approach to analyze the costs and benefits of trade liberalization on the national economy. Suppose a country wants to evaluate three alternatives of trade liberalization policy: (i) tariff reduction of zero per cent; (ii) tariff reduction of five per cent; and (iii) tariff reduction of ten per cent. The evaluation is conducted based on the benefits and costs of these policies.

The benefits can be classified as the following:

1. Economic benefits (i.e. benefit aimed at achieving economic growth), including:

(a) wider opportunities for people and business

(b) increased intra-regional trade

(c) improved efficiency (capacity building)

(d) higher valued-added job for the skilled labor and professionals (e.g. engineers, lawyers, economists)

(e) provisions of technical assistance \& financial support for domestic reform

(f) establishment of a single-integrated market (mobility skilled labor, less bureaucracy, free of flow goods)

2. Social and cultural benefits (i.e. benefits that satisfy social and cultural needs of the entire society), including:
(a) stronger social cohesiveness
(b) deeper mutual understanding
(c) political and social stability

3. Other benefits (i.e. benefits aimed at satisfying basic human needs), including:

(a) smaller development gap

(b) safer and more reliable communication

(c) more access to the environment (environment accessibility) 
(d) higher capacity to design emergency social safety net

The above breakdown leads to the following hierarchy of benefits among the three alternatives of tariff liberalization policy. The application of AHP to the benefit hierarchy provides weighting for each policy scenarios. The weight indicates the relative importance of each tariff liberalization policy alternative (see Figure 1)

By similar framework, the costs criteria can be classified as:

1. Economic costs (i.e. costs that reduces a country's independence in policy making), including:
(a) commercialization and privatization of social services
(b) rights and control over economic and social benefits
(c) foreign corporate control versus domestic corporations
(d) phased approach / corporate control
(e) necessary conditions/ requirements for proper coordination

2. Social costs, including
(a) job losses and livelihood of workers losing jobs under AFTA
(b) violations of economic, social, and cultural rights
(c) deprivation of rights to livelihood, jobs, health access
(d) massive de-industrialization/devastated industries and agriculture
(e) massive contractualization

3. Others costs (i.e. costs that reduce social status of a society), including:
(a) change in life style and traditional values
(b) erosion of policy space
(c) weakening of labor unions

Figure 2 presented in the appendix shows the cost hierarchy for the three alternatives of tariff liberalization policy. Again, we use the AHP framework to construct the cost hierarchy and to generate weight for each policy scenarios. The weight indicates the relative importance of the each tariff liberalization policy alternative.

Once the benefit and cost priorities generated, the next step is to compare the ratios of benefit priorities over the cost priorities, and evaluate the alternatives of tariff liberalization policy based on the ratios. These ratios are used to analyze the impact of tariff liberalization policy on the priority sectors in each country.

\section{Results and Discussion}

As discussed earlier, the tariff liberalization of the 12 priority sectors are the focus of our investigation. We simulate the GTAP model by employing three different scenarios of tariff reduction on agro-based, fisheries, healthcare, electronic, rubber based, wood based, textiles, and automotive sector. The three scenarios are:

(1) all the ASEAN-5 member countries reduce the import tariff to zero per cent,

(2) all the ASEAN-5 member countries reduce the import tariff to 5 per cent and

(3) all the ASEAN-5 member countries reduce the import tariff to 10 per cent.

The model was run to evaluate the possible economic impacts of tariff liberalization on national economic performances of the six individual countries (Indonesia, Singapore, Malaysia, Philippines and Thailand). Simulation results of the first scenario (reduction of tariffs to zero per cent) are depicted in Figure 3,4 and 5 (see appendix).

Figure 3 shows that the percentage of changes in output in all ASEAN-5 countries (Indonesia, Singapore, Thailand, and Philippines) has increased except for Malaysia. The percentage of increase in output for Singapore appears to be the highest (1.29\%), while Malaysia has the lowest $(-0.27 \%)$. It means that removing import tariff for the 12 priority sectors will decrease Malaysia's output by $0.27 \%$. These findings show that Singapore will get the highest "benefit" from trade liberalization, followed by Thailand, Philippines, Malaysia and Indonesia.

Similar findings are also shown in simulation results of the second scenario (reduction of import tariffs to five per cent), where Singapore receives the highest increase in output, while Malaysia gets the least. Surprisingly, when the tariffs are only cut to ten per cent, Singapore has the worst outcome compared to the other ASEAN-5 
countries (its output contracted by $2.1 \%$ ), while Indonesia has the least negative outcome (-0.4\%).

The next step is to analyze of the impact of tariff reduction on welfare gain and competitiveness, particularly on whether the tariff agreement generates equal potential economic benefits for all countries. This study adopts the "equivalent variation (EV)" concept. The "equivalent variation" concept is defined as the change in income that would allow a consumer to purchase the same quantities of all goods as before without remainder, after prices have changed. This definition also refers to the higher part of income that consumer would pay to prevent the price from changing (see Hick (1941) Meanwhile, the "terms of trade" measures a change in the export price relatively to the import price. A positive change in the value of term of trade in a country indicates that there is an improvement in term of its capital accumulation (i.e. more money is coming in from exports). The results of estimating welfare gain and competitiveness are shown in Figures 4 and 5. It is clear from Figures 4 and 5 that reducing tariff to zero per cent for all countries increases both welfare and competitiveness for all the ASEAN-5 member countries. Singapore and Thailand receive the highest welfare gains compared other country members, although Malaysia experiences losses in term of trade.

Notice that the scenario under which impact tariffs are reduced to zero is the only scenario that yields a net benefit (i.e. a benefit/cost ratio $\geq 1$ ) for all ASEAN-5 countries except Singapore. This is in contrast with our previous results obtained under the CGE approach. The latter, however, are consistent with the findings of Achsani and Partisiwi (2010), Falianty (2010), Nugroho and Yanfitri (2011) pertaining to the gains achieved by countries participating in various agreements and the fact that there still is inequality of distributions of potential economic benefit from trade liberalization under economic integration.

Table 2 presents a summary of the results obtained under the two approaches under the various tariff liberalization senarios. Under the zero percent tariff reduction scenario, CGE and AHP results diverge entirely for all five countries. However, under the five percent tariff reduction scenarios. CGE and AHP results are somewhat similar in their respective ranking for Singapore (1) and Thailand (2). Furthermore, under the ten percent scenario, the two approaches again provide somewhat similar results in term of the ranking of Thailand (2) and Indonesia (1).

Notwithstanding these similarities, the two approaches by and large appear to yield different results. This suggests that ranking is sensitive to the inclusion of non-economic factors in the analysis. Hence, our study shows that the results of previous studies that only considered economic factors should be considered with some cautions.

\section{Conclusion and Policy Implications}

This study provides additional evidence on the impact of tariff liberalization on the national economy. We analyze 12 priority sectors under the ASEAN Economic Integration (AEC) framework. The three different scenarios from the two approaches (CGE and AHP) show that overall, removing all tariffs in all-intra ASEAN of the priority sector increases output, and earn to welfare gains. Nonetheless, the distribution of economic benefits to the member countries tends to be unequal. Our results indicate that Singapore and Thailand consistently appear as countries that receive the highest gain from liberalization under the CGE approach. When we do incorporate other aspects (non-economic variables) into the analysis using the Analytical Hierarchy Process, our results show that the distribution of benefits (economic and non-economic) to member countries is again unequal. Overall, the results indicate that Indonesia and Malaysia appear to be the countries that receive the highest gain from liberalization under the AHP approach.

The results of our study based on the CGE approach are consistent with those obatined by Falianty (2006), Achsani and Siregar (2010), Achsani and Partisiwi (2010), Nugroho and Yanfitri (2011) pertaining to the gains achieved by countries participating in various agreements and the fact that inequality of distribution of potential economic benefits from trade liberalization under economic integration still exists. The results under AHP approach suggest that ranking is sensitive to the inclusion of non-economic factors in the analysis so that the findings of previous studies that only considered economic factors should be considered with a degree of caution.

Overall, our findings suggest that it is essential for members as well as stakeholders of the AEC to properly understand how to achieve maximum benefits, both in economic and non-economic terms, from economic integration.

\section{Acknowledgements}

I am particularly grateful to Gregory James, N.Achsani, and Eric Alexander Sugandi for their detailed and helpful comments on earlier drafts. Risna Triandari provided help during the research. I also would like to 
acknowledge the financial support of the University of Indonesia. An anonymous referee generously provided me suggestions and comments that improved the work, and to him I am very grateful. Of course, any remaining errors are my own.

\section{References}

Achsani, N., \& Hermanto Siregar. (2010). Toward East Asian Economic Integration: Classification of the ASEAN + 3 Economies Using Fuzzy Clustering Approach. European Journal of Scientific Research, 39(4), 489-497. http://dx.doi.org/10.1007/978-3-540-87389-1_7

Achsani N., \& Titis Partisiwi. (2010). Testing the Feasibility of ASEAN+3 Single Currency Comparing Optimum Currency Area and Clustering Approach. International Research Journal of Finance and Economics, 37, 79-84. http://www.eurojournals.com/irjfe_37_08.pdf

Arrow, Kenneth J., \& Gerard Debreu. (1954). Existence of Equilibrium for a Competitive Economy. Econometrica, 265-290. http://dx.doi.org/10.2307/1907353

Azis, I. J. (1990). AHP in the benefit -cost framework : A post evaluation of the trans-sumatra highway project. European Journal of Operational Research, 48, 38-48. http://dx.doi.org/10.1016/0377-2217(90)90059-K

Clayton, W. A., Wright, M., \& Sarver W. S. (1993). Benefit cost analysis of riverboat gambling. Mathematical and Computer Modelling, 17, 187-194. http://dx.doi.org/10.1016/0895-7177(93)90187-4

Dixit, Avinash K., \& Victor D. Norman. (1986). Gains from trade without lump-sum compensation. Journal of International Economics, 21, 111-122. http://dx.doi.org/10.1016/0022-1996(86)90008-5

Francois, J. F., \& dan Wignaraja G. (2008). Economic Implication of ASEAN Integration. Global Economy, 8(3), 1-46. http://www.relooney.info/0_Important_22.pdf

Gunning, J. W., \& M. Keyzer. (1995). Applied General Equilibrium Model for Policy Analysis, in J. Behrman and T.N. Srinivasan (eds.), Handbook of Development Economics, VIII-A, Amsterdam: Elsevier, 2025-2107.

Deardorff, Alan V. (1984). The General Validity of the Law of Comparative Advantage. Journal of Political Economy, 88, 941-57. http://dx.doi.org/10.1086/260915

Urata, Shujiro, \& Kozo Kiyota. (2003). The Impact of an East Asia FTA on Foreign Trade in East Asia, NBER Working Paper No. 10173 (Cambridge, Massachusetts, National Bureau of Economic Research).

Falianty, T. A. (2006). Optimum Currency Area: Case Study of ASEAN-5 Countries [Dissertation], Faculty of Economics, the University of Indonesia.

Handfield, R, Walton S, V., Sroufe, R., \& Melnyk, S. (2002). Applying environmental criteria to supplier assessment: A study in the application of the Analytical Hierarchy Process. European Journal of Operational Research, 141, 70-87. http://dx.doi.org/10.1016/S0377-2217(01)00261-2

Hertel, Thomas W. (ed). (1997). Global Trade Analysis: Modeling and Applications (Cambridge and New York, Cambridge University Press). Global Trade Analysis, http://dx.doi.org/10.1017/CBO9781139174688 . (2006). Chapter 1 Introduction. GTAP 6 Data Base Documentation, GTAP Resource No. 1797 (West Lafayette, Indiana, Center for Global Trade Analysis, Purdue University).

Hick, J. R. (1942). Consumers' Surplus and Index-Numbers. Review of Economic Studies, 9(2), 126-137. http://dx.doi.org/10.2307/2967665

Lloyd, Peter J., \& Donald MacLaren. (2004). Gains and losses from regional trading agreements: a survey. Economic Record, 80(251), 445-467. http://dx.doi.org/10.1111/j.1475-4932.2004.00202.x

Mukhopadhyay, K., \& dan Thomassin, P. J. (2008). Economic impact of East and South-East Asian free trade agreements. Asia-Pacific Trade and Investment Review, 4, 57-81.

Nugroho, \& Yanfitri. (2011). The potential Impact of establishing Single Market Integration on Indonesia's Economy, Occassional Paper, Bank of Indonesia, No. OP/02/2011.

Pardo-Calvo, Freund, C.L., \& Omelas, L. (2009). The ASEAN Free Trade Agreement: Impact on Trade Flows and External Trade Barriers. The World Bank. Policy Research Working Paper 4960.

Saaty, T. L. (1990). How to make a decision: The analytic hierarchy process. European Journal of Operational Research. Volume, 48(1), 9-26. http://dx.doi.org/10.1016/0377-2217(90)90057-I

Shields, C. R., \& J. F. François. (eds). (1994). Modeling Trade Policy: Applied General Equilibrium Assessments of North American Free Trade. New York: Cambridge University Press. 
Wedley, W. C, Choo, Eng Ung, \& Schoner, Bertram. (2001). Magnitude adjustment for AHP benefit/cost ratios. European Journal of Operational Research. European Journal of Operational Research, 133(2), 342-351. http://dx.doi.org/10.1016/S0377-2217(00)00302-7

Wing. I. S. (2004). Computable General Equilibrium Models and Their Use in Economy Wide Policy Analysis. Technical Note No.6. MIT Joint Program on the Science and Policy of Global Change.

\section{Appendix}

Table 1. Sector Aggregation

\begin{tabular}{lll}
\hline No & Aggregated Sector & Product \\
\hline 1. & Agro based product & $\begin{array}{l}\text { Paddy rice; wheat; cereal grain nec; vegetable, fruit, nut; sugar cane, sugar beat; plant base fibers; } \\
\text { crops nec; forestry; rice; sugar; beverage and tobacco product }\end{array}$ \\
2. & Air Transport & Air transport \\
3. & Automotive & Motor vehicle product; transport equipment \\
4. & E-ASEAN & Financial services; insurance; business services \\
5. & Electronic goods & Electronic equipment; machinery equipment; electricity \\
6. & Fisheries & Fishing \\
7. & Health Product & Public administration, health, defences /education \\
8. & Rubber & Chemical, plastic product, rubber \\
9. & Texting and clothing & Wool, silk worm cocoons; textiles; wearing apparel; leather product \\
10 & Tourism & Trade; communication; recreation and other services \\
11. & Wood & Wood products, paper product; publishing \\
12 & Logistic & Trans nec, sea transport \\
\hline
\end{tabular}

Source: GTAP Version 7 database

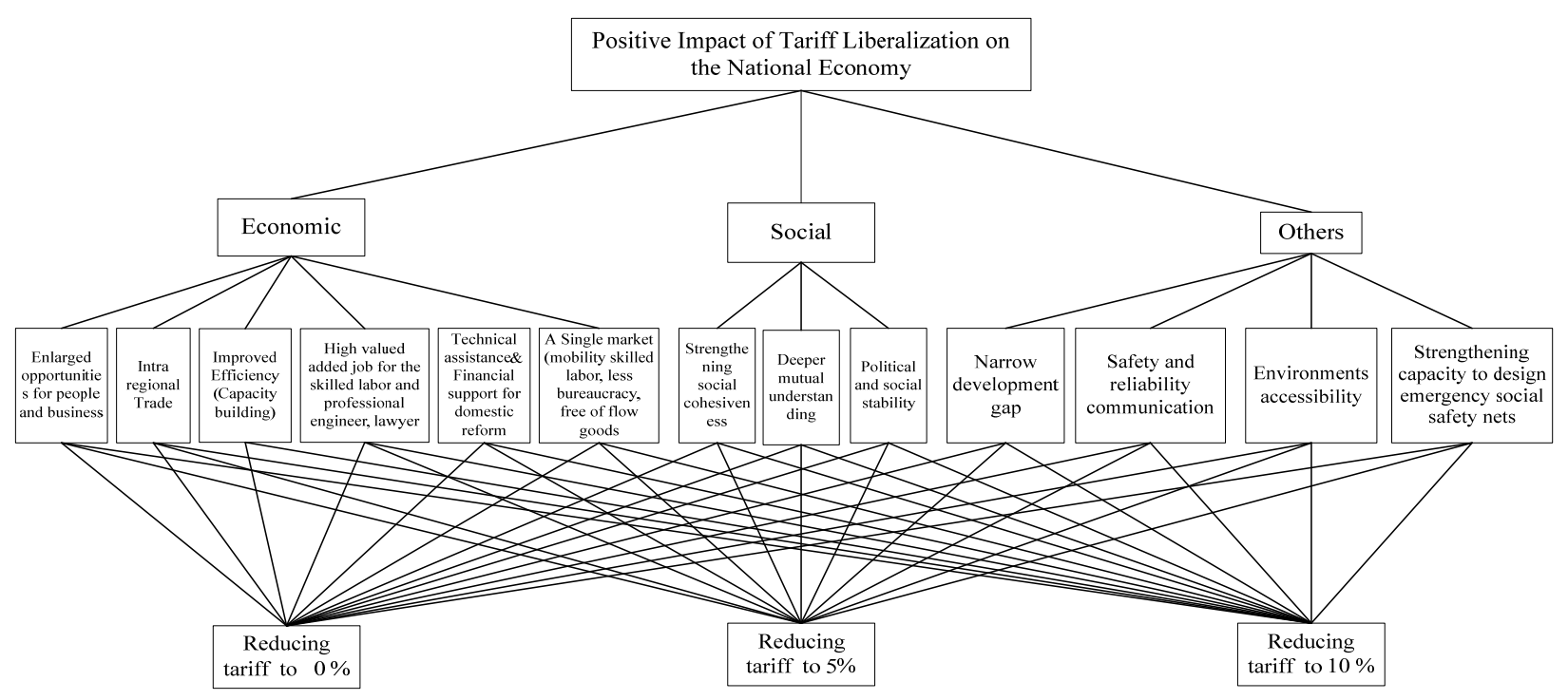

Figure 1. Hierarchy for Positive Impact of Tariff Liberalization on the National Economy 


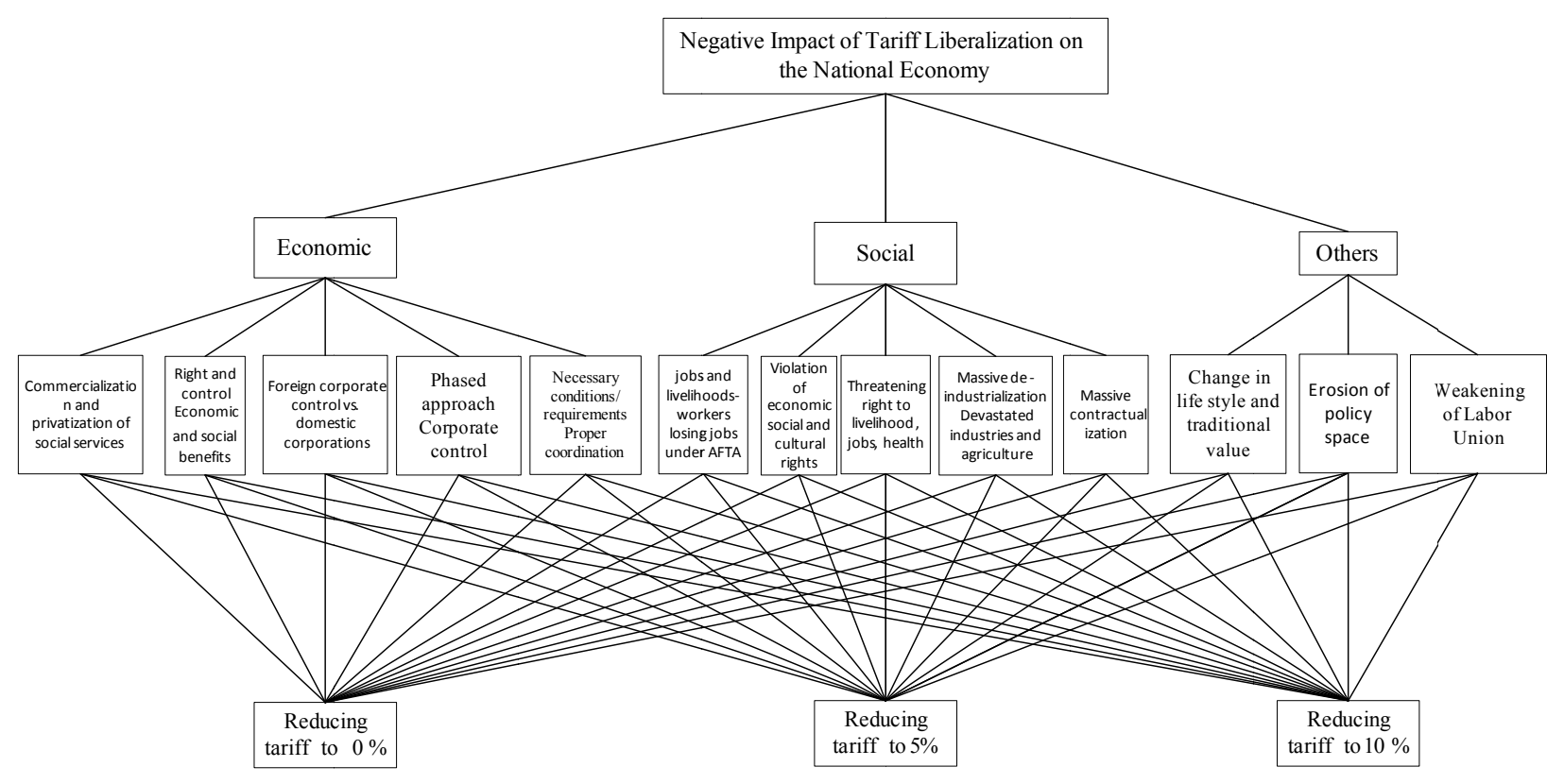

Figure 2. Hierarchy for Negative Impact of Tariff Liberalization on the National Economy

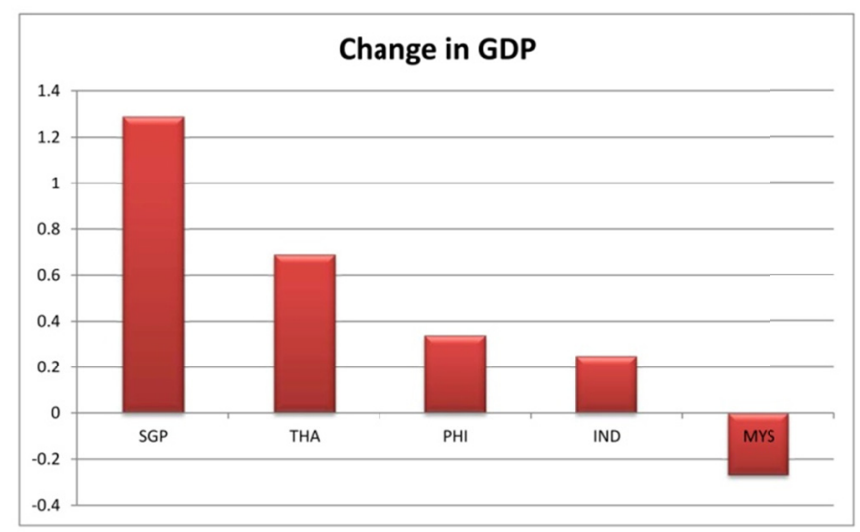

Figure 3. Percentage change in the GDP and Import value under zero per cent of tariff liberalization scenario

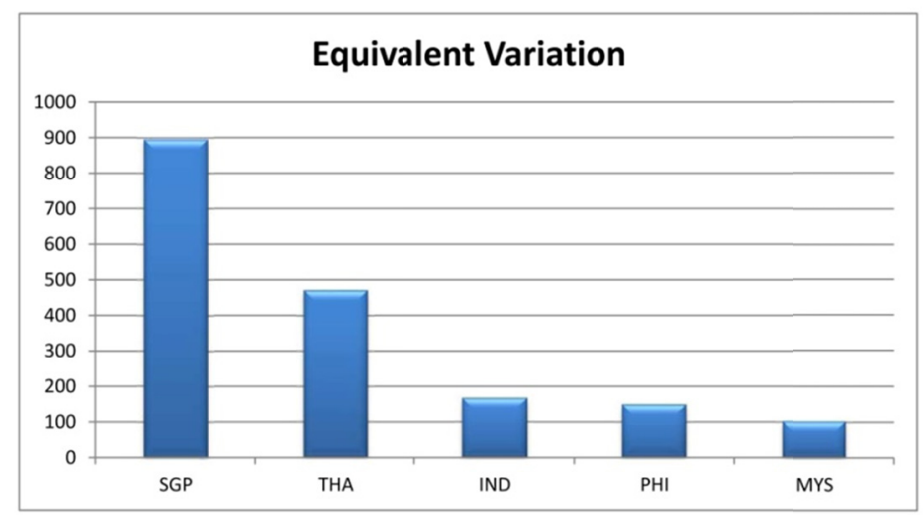

Figure 4. Percentage change in the Equivalence of Variation under zero per cent of tariff liberalization scenario 


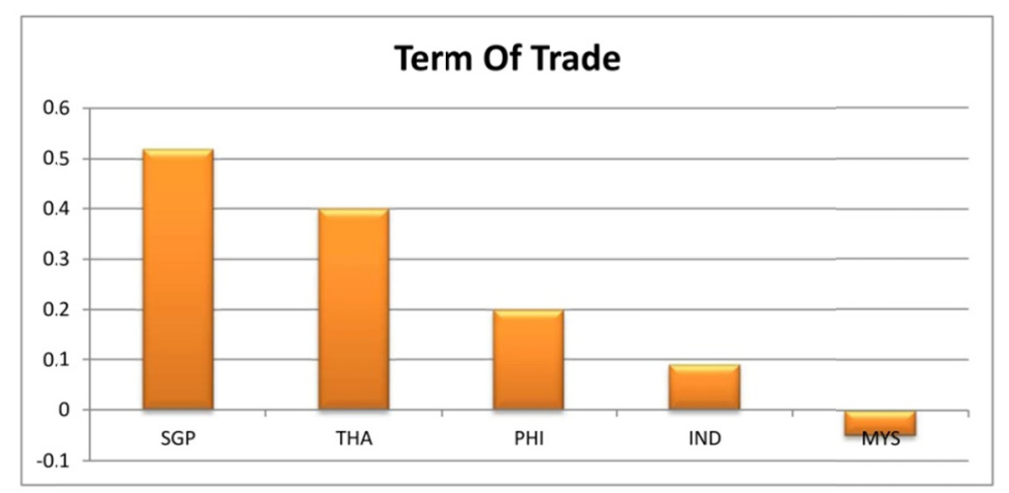

Figure 5. Percentage change in the Term of Trade under zero per cent of tariff liberalization scenario

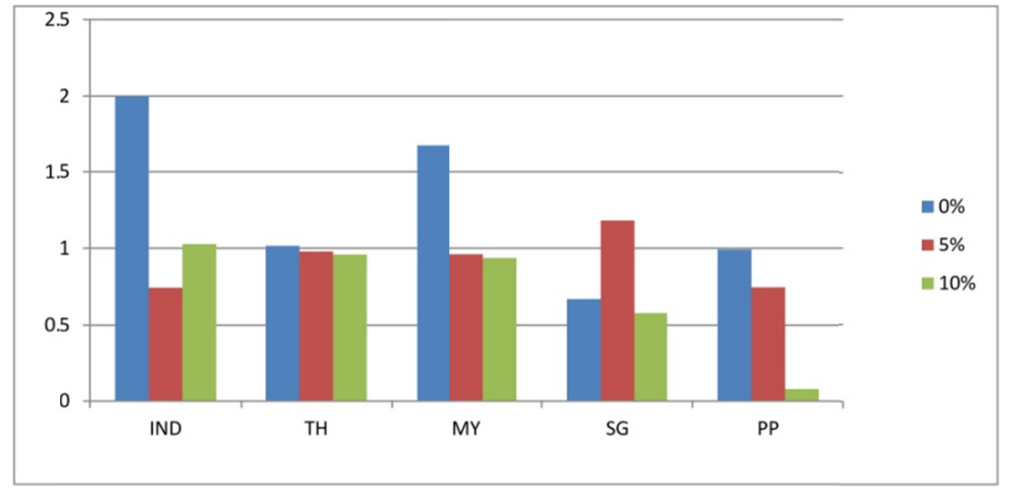

Figure 6. Chart of the benefit-cost ratio of three possible scenarios for each of the ASEAN-5 country members

Table 2. Summary results of the CGE and AHP under various tariff liberalization scenarios

\begin{tabular}{|c|c|c|c|c|}
\hline \multirow[t]{2}{*}{ scenarios } & \multicolumn{3}{|c|}{ CGE } & \multirow{2}{*}{$\frac{\mathrm{AHP}}{\mathrm{B} / \mathrm{C}}$} \\
\hline & $\Delta \%$ GDP & EV & TOT & \\
\hline \multirow[t]{5}{*}{$0 \%$} & Singapore (1) & Singapore (1) & Singapore (1) & Singapore (5) \\
\hline & Thailand (2) & Thailand (2) & Thailand (2) & Thailand (3) \\
\hline & Indonesia (4) & Indonesia (3) & Indonesia (4) & Indonesia (1) \\
\hline & Malaysia (5) & Malaysia (5) & Malaysia (5) & Malaysia (2) \\
\hline & Philippine (3) & Philippines (4) & Philippines (3) & Philippines (4) \\
\hline \multirow[t]{5}{*}{$5 \%$} & Singapore (1) & Singapore (1) & Singapore (2) & Singapore (1) \\
\hline & Thailand (4) & Thailand (5) & Thailand (3) & Thailand (2) \\
\hline & Indonesia (3) & Indonesia (2) & Indonesia (4) & Indonesia (5) \\
\hline & Malaysia (5) & Malaysia (4) & Malaysia (5) & Malaysia (3) \\
\hline & Philippines (2) & Philippines (3) & Philippines (1) & Philippines (4) \\
\hline \multirow[t]{5}{*}{$10 \%$} & Singapore (5) & Singapore (1) & Singapore (3) & Singapore (4) \\
\hline & Thailand (3) & Thailand (5) & Thailand (2) & Thailand (2) \\
\hline & Indonesia (1) & Indonesia (2) & Indonesia (1) & Indonesia (1) \\
\hline & Malaysia (2) & Malaysia (4) & Malaysia (5) & Malaysia (3) \\
\hline & Philippines (4) & Philippines (3) & Philippines (2) & Philippines (5) \\
\hline
\end{tabular}

